\title{
Sugarcane Productivity Influenced by Irrigation Techniques and Crop Establishment Methods
}

\author{
S. Anbumani* E. Jamuna and M. Pandian \\ Agricultural College and Research Institute, Thiruvannamalai-606 753, Tamil Nadu, India \\ *Corresponding author
}

\begin{tabular}{|l|}
\hline Ke y w o r d s \\
$\begin{array}{l}\text { Furrow Irrigation, } \\
\text { Drip irrigation, Sett } \\
\text { planting and Chip } \\
\text { bud seedling }\end{array}$ \\
\hline Article Info \\
\hline $\begin{array}{l}\text { Accepted: } \\
\text { 07 March } 2020 \\
\text { Available Online: } \\
\text { 10 April } 2020\end{array}$ \\
\hline
\end{tabular}

\begin{abstract}
A B S T R A C T
Farmers participatory research was conducted at Viluppuram district in sugarcane crop to find out the feasibility of Sustainable Sugarcane Initiative (SSI) promotion in tank fed irrigated area under the World Bank funded TN-IAMWARM Project. The OFT's were conducted in 10 farmers holdings at 5 villages with 3 treatments viz., conventional method, sett planting with Sub surface drip irrigation (SSDI) and Sustainable Sugarcane initiative (SSI) during 2011-14.Results revealed that more number of millable cane (NMC) of 1.26 lakhs under SSI, followed by 1.19 lakh in sett planting with SSDI. Lowest NMC of 1.06 in conventional method. The number of internodes and internode length also varied between the establishment methods and irrigation techniques. Individual cane weight was higher in SSI $1.55 \mathrm{~kg}$, which was followed by $1.42 \mathrm{~kg} / \mathrm{cane}$ in sett planting under SSDI. Higher cane yield of $159.6 \mathrm{t} / \mathrm{ha}$ in SSI which was followed by setts planting under SSDI (138.5).Cane yield increased to the tune of $40 \%$ over conventional planting and $22 \%$ over sett planting with SSDI .Quality parameters also showed a striking differences among the treatments. Enhanced water productivity of 9.73 and 10.36 was recorded under SSI and 8.05 and 8.38 was under sett planting with SSDI in main and ratoon crop. Lowest water productivity was in conventional planting with a tune of $5.32 \& 5.04 \mathrm{~kg} / \mathrm{m}^{3}$ in main and ratoon crop respectively. Higher net income of Rs. 2.12 lakhs/ha in main crop and Rs.2.52 lakhs/ha in ratoon crop was recorded in SSI, which was followed by sett planting under SSDI.
\end{abstract}

\section{Introduction}

Sugarcane is an important industrial cum commercial crop in India by supporting 40 million farmers and 50 million employs. During the last 10 years, sugarcane production in India has been fluctuating between 233 million tonnes and 355 million tonnes. Similarly, the productivity at the farm level is as low as $66 \mathrm{t} / \mathrm{ha}$ (Anon, 2018). India is having a second largest area under sugarcane cultivation in the world next to Brazil, the industry is currently under in great pressure. Though, Uttar Pradesh dominates in production with 134 MT followed by Maharashtra with 79 MT, in terms of productivity, Tamil Nadu leads with 105 t/ha followed by Karnataka (88 t/ha) and Andhra 
Pradesh (82 t/ha). Despite of long tradition and owning more area in India, sugarcane yields are unimpressive, especially less profitable. Sugarcane cultivation and the sugar industry in India are facing serious challenges due to various internal and external factors. The yield is in the declining trend in recent years due to increased cost of cultivation (Anon, 2015). To tackle this decreasing trend in area it is necessary to bring some changes in cultivation aspects which will improve the profitability. Sugarcane as a $\mathrm{C}_{4}$ plant, having most efficient converters of solar energy, thus having potential to produce huge amount of biomass (Naidu, 2003). The plant also can grow very quickly by more efficient on using $\mathrm{CO}_{2}$ and is resistant to drought and high temperature. With these potential, it is possible to increase the productivity of the crop by adopting Sustainable Sugarcane initiative practices.

Rapid decline in irrigation water potential and low water use efficiency under flood irrigation is a serious threat for more water requiring crop like sugarcane to face moisture stress at any stage of the crop (Narayanamoorthy,2013) and he stated that drip irrigation increases water use efficiency and crop productivity. Irrigation water availability is major constraint which affects the productivity and profitability in sugarcane (Vinodgoud, 2011).Bud chip seedling method coupled with drip irrigation in sugarcane could give higher cane yield. Bud chip system is an improved method of sugarcane planting and requires only 5000 numbers of single budded chips (450-500 kgs of seed material) for planting one acre from the experiences of the earlier studies. Keeping these in view, the Water Technology Centre (TNAU) has taken frontier initiatives through World Bank Funded TN-IAMWARM project to study the suitability and economic feasibility of Sustainable Sugarcane Initiative (SSI) in hands with sugar industries during 2011-14 at
Viluppuram district. Framers participatory research was conducted to compare the two methods of planting viz., sett and seedlings under furrow irrigation and sub surface drip irrigation methods. The objective of the above study is to find out the feasibility and viability of Sustainable Sugarcane Initiative at farmers doorstep in a participatory mode.

\section{Materials and Methods}

The On Farm testing (OFT's) was conducted in 10 farmers holdings at 5 villages during 2011-12 to 2013-14 (2 years including one Main crop and Ratoon crop) at Varaghanadhi sub basin through Tamil Nadu Irrigated Agriculture Modernization and Water Bodies Restoration and Management (TNIAMWARM) Project under the funding of World Bank. The study area is located in 5 villages viz., Pidagam, Virattikuppam, V.Sathanur, Rettanai and Thenper of Villupuram district of Tamil Nadu .The climate of the experimental site is semi arid characterized by hot summer with mean maximum temperature of $38 \pm 5^{0} \mathrm{C}$ during June and cool winter with mean minimum temperature of $4 \pm 2^{0} \mathrm{C}$ during December. The average annual rainfall in the study area varies from 1050-1200 $\mathrm{mm}$. The soil was medium in fertility status in terms of organic carbon, available nitrogen, phosphorus and high available potassium. The surface with a sandy loam to clay loam in texture $(0-30 \mathrm{~cm})$ soil of $\mathrm{pH}$ ranges from 7.21-7.9, electrical conductivity $0.302-0.56 \mathrm{dS} / \mathrm{m}$. Soil $\mathrm{pH}$ and EC were determined using 1:2 soil: water suspension (Jackson 1967). Soil organic carbon content was determined by Walkley and Black's (1934) rapid titration method. This experiment was conducted with sub surface drip fertigation (SSDI). Laterals $(16 \mathrm{~mm})$ with $40 \mathrm{~cm}$ emitter spacing with 2 litres/hour discharge was installed at $20 \mathrm{~cm}$ depth at $1.5 \mathrm{~m}$ spacing. Different establishment methods viz., sett planting with 
furrow and drip irrigation and SSI in randomized block design at 10 farmer's holdings as 10 replications in 0.2 ha field size for the each treatment.

In Conventional planting 75,000 two budded sett/ha (10 t/ha) were planted as end to end at $75-80 \mathrm{~cm}$ spacing between row with ridges and furrow irrigation as $T_{1}$. Sub surface drip irrigation at $1.50 \mathrm{~m}$ lateral spacing and paired row planting of 75,000 two budded sett/ha (10 $\mathrm{t} / \mathrm{ha}$ ) at 45:105 $\mathrm{cm}$ spacing as $\mathrm{T}_{2}$. Sub surface drip irrigation at $1.50 \mathrm{~m}$ lateral spacing with 30 days old pro tray grown chip bud seedling @ 5000 in single row planting at $1.50 \times 0.6 \mathrm{~m}$ spacing as SSI $\left(\mathrm{T}_{3}\right)$. Fertigation schedule was given common for $\mathrm{T}_{2} \& \mathrm{~T}_{3}$ (given in Table 1). Irrigation was given at $100 \% \mathrm{PE}$ in drip irrigation. In Chip bud seedling planted plots mother shoot clipping was done at 20-30 days after planting (DAP). Sugarcane variety Co 86032 was chosen for the study in all the locations with irrespective of the treatments. Mini mill test was done for the qualitative analysis of the sugarcane samples at the time of harvest. The biometric observation was taken in 10 places at each OFT's and it was pooled for the analysis. To work out the Cane price paid @ Rs.2350/tonne to the farmers was considered for working out the cost of cultivation. Drip irrigation was installed to the farmers at $75 \%$ subsidy as per the norms of the Government of Tamil Nadu. Remaining cost towards farmers contribution was splitted into 5 years for working out cost of production@ Rs.10,000/year.

The crop was planted during December 2011 to January 2012 and the main crop was harvested in 2012-13 \& ratoon crop was continued and harvested during 2013-14.. Tillers were counted 120 days after planting and number of millable canes (NMC), Number of internodes/plant, internode length (cm) at time of harvest from net plot area of each plot. Single cane weight of 10 detopped and detrashed canes was taken randomly from each plot and averaged out. Mini mill test was done for the quality parameters. Statistical analysis was carried out by using by Gomez and Gomez, 1984.

\section{Results and Discussion}

Results emanated from the farmers participatory research in 10 fields with pooled values reveals that different establishment methods owes greater influence on germination percentage and plant population in sugarcane crop. Setts planting under ridges furrow method at $75-80 \mathrm{~cm}$ spacing are being the common practice which is in vogue among the majority of the farmers but this method has shown a drastic reduction in germination percentage to $57.2 \%$ in the main field at irrespective of the irrigation methods. Planting of Chip bud seedlings found to have exuberant performance in term of sprouting and also in field establishment $(91.5 \%)$ due to conducive environment for the individual buds under shade net condition and transplanting under drip irrigation has shown significantly better establishment than setts planting as opined by Kapur et al., (2011) and Kabita Mishra (2019). Almost $42 \%$ buds were failed to sprout under main field in furrow irrigation which leads to economical loss by fetching less number of millable cane (NMC) and cane yield (Vijayakumar and Suresh,2010). Even under drip irrigation with setts planting has also shown $23 \%$ failure in germination under main field condition (Table 2).

Despite of the poor germination, more number of tillers was registered under conventional planting, but the conversion of NMC is very low (72\%). More conversion was observed chip bud seedlings planting with drip irrigation (83\%).This increase in higher NMC was also due to better and early conversion of tillers to millable canes 
(Khandagave et al., 2005) . The higher NMC production under sub surface drip fertigation system was mainly due to the enhanced supply of plant nutrients and continuous availability of water below the root zone of crop without any stress. Significant difference was found between establishment methods on growth and yield attributes. Number of millable cane (NMC) is important yield determinant in sugarcane and its intensity and individual cane weight are key dictators of cane productivity. More NMC (1,26,500/Ha ) recorded under SSI which was followed by sett planting under SSDI .Least NMC was in conventional planting $(1,06,500)$. No. of internodes /plant, internode length, individual cane weight also significantly higher in SSI. Regarding cane yield 40.5 percent increased over conventional planting and 15.2 percent over sett planting under SSDI in the main crop (Table 1). The increase in individual cane weight was mainly due to increased individual cane length, number of internodes/plant and the favourable influence was better and adequate supply of required quantity of water and nutrients at the right time and right place. Increasing row spacing increased the individual cane weight as stated by Gaddanakeri et al., 2007 and Logananthan et al., 2012.Tamilselvan (2006) revealed that planting of seedlings increases the cane productivity due to early tillering with synchronized growth of the stalks.

In ratoon crop reduction in the No. of tillers and NMC was noticed under irrespective of the planting methods and irrigation techniques, but drastic reduction was in conventional planting to tune of $8 \%$ than under drip irrigated field at irrespective of the establishment methods, which results reduction in yield attributing parameters viz., internode length and cane weight under conventional planting but the No. of internode /plant is more in all the treatments. SSI has greater influences over rest of treatments on individual cane weight which altogether significantly enhanced the cane yield of 67 percent over conventional planting and 27 percent over setts planting under SSDI (Figure 1). Setts planting with SSDI has greater yield difference of 36 percent over conventional planting in ratoon crop (Table 2) in accordance with Waykar et al., 2003.GuiFen-Chen et al., 2012 opined that drip irrigation promoted the plants to grow earlier and faster, more millable canes and stalk length paved for higher cane yield. SSI performed positively in ratoon crop than sett planting either furrow of drip irrigation method due to maintenance of NMC and increased cane weight as opined by Pandian and Anbumani (2015).

\section{Quality analysis}

Qualitative analysis was carried out by mini mill test which also exhibited higher juice purity $84.1 \%$ in SSI plots than conventional planting $81.6 \%$. Likewise, the polarity percentage and brix reading also been striking differences over conventional planting (Table 4). Particularly ratoon crop has excellent appreciation in the qualitative parameters in sett planting under SSDI and SSI. This might be due to extended duration and synchronized millable cane in SSI .Drip irrigation not only enhanced the cane productivity, it also paved way for maximizing the sugar recovery. This in accordance with the findings of Sathiyaraj and Sathyapriya.2017.

\section{Economic analysis}

Despite of the cost incurred for the installation of SSDI the results from the 10 farmers holdings and pooled mean has showed that appreciable yield advantage and also profitability. More net income and benefit cost ratio was Rs. 2.12 lakhs/ha \& Rs.2.30 in main crop and Rs.2.52 lakhs/ha \& Rs.2.84 in ratoon crop was obtained, which 
was followed by sett planting under SSDI has net income \& benefit cost ratio of Rs 1.61 lakhs/ha \& Rs.1.98 in main crop and Rs.1.78 lakhs/ha \& Rs.2.29 in ratoon crop (Table 5). Less net income with benefit cost ratio was obtained under conventional planting. Ratoon crop has higher profitability over main crop due to less cost of production at irrespective of the treatments as stated by Patil et al., 2006.

\section{Water productivity}

Sub Surface Drip Irrigation has greater difference in water savings over ridges and furrow irrigation, particularly planting of chip seedlings has an advantage of one month reduction in main field duration which leads to $800 \mathrm{~m}^{3}$ water saving over sett planting under SSDI. Water productivity of $8.05 \mathrm{~kg} / \mathrm{m}^{3}$ in sett planting under SSDI and $9.73 \mathrm{~kg} / \mathrm{m}^{3}$ in SSI during main season crop over the ridges and furrow irrigation $\left(5.32 \mathrm{~kg} / \mathrm{m}^{3}\right)$. In ratoon crop, SSDI at irrespective of the establishment method has shown $3600 \mathrm{~m}^{3}$ saving in water and enhanced water productivity of $8.38 \mathrm{~kg} / \mathrm{m}^{3}$ in sett planting under SSDI and $10.36 \mathrm{~kg} / \mathrm{m}^{3}$ in SSI during main season crop over the ridges and furrow irrigation $\left(5.04 \mathrm{~kg} / \mathrm{m}^{3}\right.$ (Table 5). Drip irrigation has found to have 22.5 per cent water saving over conventional planting in ratoon crop, similar observation was in main crop with a saving of water up to 28 percent over conventional irrigation. Hapse et al., 1991 reported that drip irrigation in sugarcane compared to furrow irrigation increases water saving and water use efficiency almost doubled.

Table.1 Fertigation schedule for sugarcane ( $\mathrm{kg} / \mathrm{ha})$

\begin{tabular}{|c|c|c|c|}
\hline Crop stage (days after planting) & Nitrogen & Phosphorus & Potassium \\
\hline $\mathbf{0 - 3 0}$ & 39.4 & 0 & 0 \\
\hline $\mathbf{3 1 - 6 0}$ & 50.6 & 26.25 & 9.0 \\
\hline $\mathbf{6 1 - 9 0}$ & 56.5 & 20.50 & 14.50 \\
\hline $\mathbf{9 1 - 1 2 0}$ & 60.2 & 16.25 & 16.00 \\
\hline $\mathbf{1 2 1 - 1 8 0}$ & 57.8 & 0 & 40.50 \\
\hline $\mathbf{1 8 1 - 2 2 0}$ & 10.5 & 0 & 35.0 \\
\hline Total & $\mathbf{2 7 5}$ & $\mathbf{6 3}$ & $\mathbf{1 1 5}$ \\
\hline
\end{tabular}

Table.2 Growth and yield attributing factors Influenced by crop establishment and irrigation methods for main crop (2011-12 to 2012-13)

\begin{tabular}{|l|c|c|c|c|c|c|c|}
\hline Treatments & $\begin{array}{c}\text { Establis } \\
\text { hment } \\
\text { \% }\end{array}$ & $\begin{array}{c}\text { No. of } \\
\text { tillers } \\
\mathbf{6 0 0 / h a}\end{array}$ & $\begin{array}{c}\text { NMC } \\
\mathbf{0 0 0} / \mathbf{h a}\end{array}$ & $\begin{array}{c}\text { Internode } \\
\text { s/plant }\end{array}$ & $\begin{array}{c}\text { Internode } \\
\text { length } \\
\text { (cm) }\end{array}$ & $\begin{array}{c}\text { Cane wt. } \\
\text { (kg/plant) }\end{array}$ & $\begin{array}{c}\text { Cane } \\
\text { yield } \\
\text { (t/ha) }\end{array}$ \\
\hline $\begin{array}{l}\text { T1 : conventional } \\
\text { method }\end{array}$ & 57.2 & 136.8 & 106.5 & 22.3 & 15.8 & 1.05 & 111.8 \\
\hline $\begin{array}{l}\text { T2: SSDI with } \\
\text { sett planting }\end{array}$ & 76.9 & 149.5 & 119.6 & 28.6 & 21.4 & 1.42 & 138.5 \\
\hline T3: SSI & 91.5 & 148.0 & 126.5 & 30.8 & 22.6 & 1.55 & 159.6 \\
\hline S.Ed. & 2.82 & 1.68 & 3.64 & 0.7 & 0.6 & 0.05 & 1.8 \\
\hline CD (p=0.05) & 6.09 & 3.95 & 7.40 & 1.9 & 1.4 & 0.11 & 4.01 \\
\hline
\end{tabular}


Table.3 Growth and yield attributing factors Influenced by crop establishment and irrigation methods for ratoon crop (2012-13 to 2013-14)

\begin{tabular}{|l|c|c|c|c|c|c|}
\hline Treatments & $\begin{array}{c}\text { No.of tillers } \\
\mathbf{0 0 0} / \mathbf{h a}\end{array}$ & $\begin{array}{c}\text { NMC } \\
\mathbf{0 0 0} / \mathbf{h a}\end{array}$ & $\begin{array}{c}\text { Internodes/ } \\
\text { plant }\end{array}$ & $\begin{array}{c}\text { Internode } \\
\text { length } \\
\text { (cm) }\end{array}$ & $\begin{array}{c}\text { Cane wt. } \\
\text { (kg/plant) }\end{array}$ & $\begin{array}{c}\text { Cane } \\
\text { iield } \\
\text { (t/ha) }\end{array}$ \\
\hline $\begin{array}{l}\text { T1 : } \\
\text { conventional } \\
\text { method }\end{array}$ & 138.6 & 98.6 & 23.1 & 14.9 & 0.95 & 98.7 \\
\hline $\begin{array}{l}\text { T2: SSDI with } \\
\text { sett planting }\end{array}$ & 140.5 & 116.5 & 28.5 & 20.6 & 1.48 & 134.2 \\
\hline T3: SSI & 141.8 & 124.8 & 29.7 & 22.2 & 1.61 & 165.8 \\
\hline S.Ed. & 1.4 & 3.56 & 0.8 & 0.7 & 0.03 & 1.9 \\
\hline CD (p=0.05) & 3.5 & 7.24 & 1.9 & 1.5 & 0.07 & 4.1 \\
\hline
\end{tabular}

Table.4 Quality attributing parameters Influenced by crop establishment and irrigation methods for main and ratoon crop

\begin{tabular}{|l|c|c|c|c|c|c|}
\hline & \multicolumn{3}{|c|}{ Main Crop } & \multicolumn{3}{c|}{ Ratoon crop } \\
\hline Treatments & Brix \% & Pol \% & $\begin{array}{c}\text { Purity } \\
\%\end{array}$ & Brix \% & Pol \% & Purity \% \\
\hline $\begin{array}{l}\text { T1 : conventional } \\
\text { method }\end{array}$ & 19.8 & 13.9 & 81.6 & 20.7 & 14.9 & 82.1 \\
\hline $\begin{array}{l}\text { T2: SSDI with } \\
\text { sett planting }\end{array}$ & 20.7 & 14.3 & 83.5 & 21.3 & 15.3 & 84.2 \\
\hline T3 : SSI & 21.0 & 14.6 & 84.1 & 21.8 & 15.4 & 84.9 \\
\hline
\end{tabular}

Table.5 Economic Analysis among the crop establishment and irrigation methods for main and ratoon crop

\begin{tabular}{|l|c|l|l|l|l|l|l|l|l|}
\hline & \multicolumn{4}{|c|}{ Main Crop (Rs./ha) } & \multicolumn{4}{c|}{ Ratoon crop ( Rs./ha) } \\
\hline Treatments & $\begin{array}{l}\text { Gross } \\
\text { income }\end{array}$ & $\begin{array}{l}\text { Cost of } \\
\text { Production }\end{array}$ & $\begin{array}{l}\text { Net } \\
\text { Income }\end{array}$ & BCR & $\begin{array}{l}\text { Gross } \\
\text { income }\end{array}$ & $\begin{array}{l}\text { Cost of } \\
\text { Production }\end{array}$ & $\begin{array}{l}\text { Net } \\
\text { Income }\end{array}$ & BCR \\
\hline $\begin{array}{l}\text { T1 : } \\
\text { conventional } \\
\text { method }\end{array}$ & 262730 & 141210 & 121520 & 1.86 & 231945 & 111250 & 120695 & 2.08 \\
\hline $\begin{array}{l}\text { T2: SSDI with } \\
\text { sett planting }\end{array}$ & 325475 & 164285 & 161190 & 1.98 & 315370 & 137650 & 177720 & 2.29 \\
\hline T3: SSI & 375060 & 162915 & 212145 & 2.30 & 389630 & 136850 & 252780 & 2.84 \\
\hline
\end{tabular}


Table.6 Water productivity influenced by crop establishment and irrigation methods for main and ratoon crop

\begin{tabular}{|l|c|c|c|c|c|c|c|c|}
\hline & \multicolumn{4}{|c|}{ Main Crop } & \multicolumn{4}{c|}{ Ratoon crop } \\
\hline Treatments & $\begin{array}{c}\text { Cane } \\
\text { yield } \\
(\mathrm{t} / \mathrm{ha})\end{array}$ & $\begin{array}{c}\text { Water } \\
\text { Consume } \\
\mathrm{d}\left(\mathrm{m}^{3} / \mathrm{ha}\right)\end{array}$ & $\begin{array}{c}\text { Water } \\
\text { Productivity } \\
\mathrm{kg} / \mathrm{m}^{3}\end{array}$ & $\begin{array}{c}\% \\
\text { saving } \\
\text { in water }\end{array}$ & $\begin{array}{c}\text { Cane } \\
\text { yield } \\
(\mathrm{t} / \mathrm{ha})\end{array}$ & $\begin{array}{c}\text { Water } \\
\text { Consume } \\
\mathrm{d}\left(\mathrm{m}^{3} / \mathrm{ha}\right)\end{array}$ & $\begin{array}{c}\text { Water } \\
\text { Productivity } \\
\mathrm{kg} / \mathrm{m}^{3}\end{array}$ & $\begin{array}{c}\% \\
\text { saving } \\
\text { in water }\end{array}$ \\
\hline $\begin{array}{l}\text { T1 : } \\
\text { conventional } \\
\text { method }\end{array}$ & 111.8 & 21000 & 5.32 & - & 98.7 & 19600 & 5.04 & - \\
\hline $\begin{array}{l}\text { T2: SSDI with } \\
\text { sett planting }\end{array}$ & 138.5 & 17200 & 8.05 & 22.1 & 134.2 & 16000 & 8.38 & 22.5 \\
\hline T3: SSI & 159.6 & 16400 & 9.73 & 28.0 & 165.8 & 16000 & 10.36 & 22.5 \\
\hline
\end{tabular}

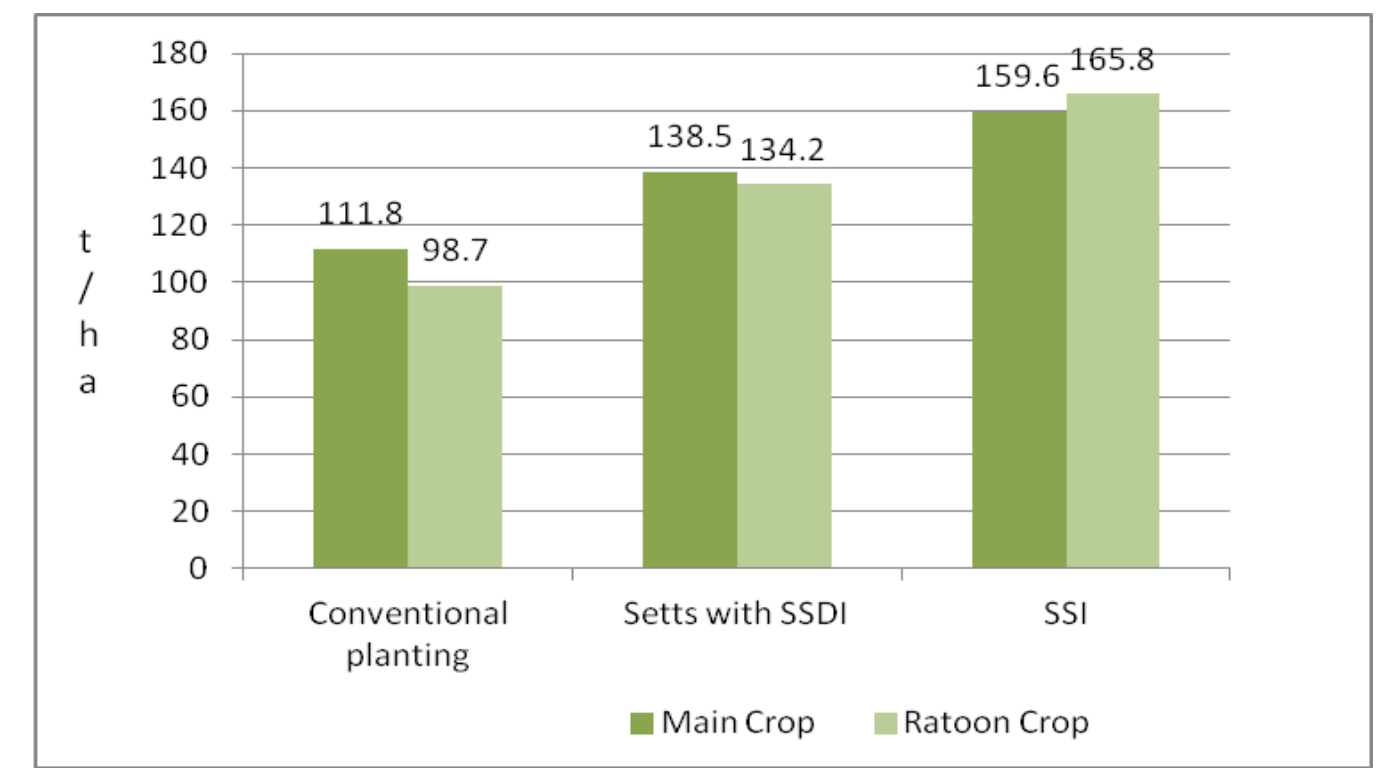

Figure.1 Influence of establishment methods and irrigation techniques on cane yield in main and ratoon crops (2011-2014)

SSI has greatly influenced the yield attributes like NMC and individual cane weight. It also paved way for maintaining the NMC in roatoon crop than conventional planting. Drip irrigation has water saving as well as qualitative improvement in both sets and seedlings planting under SSDI.

The reduction seed material up to $90 \%$, saving in irrigation water up to $28 \%$ coupled with pumping hours, minimized the externally applied manures and fertilizers, and maximize profitability is interesting observation from the SSI even in ratoon crop denotes the sustainable cane farming by judicious use of natural resources.

\section{References}

Anonymous. 2015. Price Policy for Sugarcane: 2016-17 Sugar Season, Commission for agricultural costs and prices, Department of agriculture and cooperation, Ministry of agriculture, 
Government of India, New Delhi, p 80. Anonymous. (2018). $3^{\text {rd }}$ Advance estimate for sugar season 2017-18 by Department of agriculture and Farmers welfare, Vol.49 (7). pp64-67.

Gaddanakeri , S.A., Kambar Biradar and Nadgouda, B.T. (2007). Response of shy tillering variety to wider row spacing and clipping. Karnataka $J$. Agric. Sci., 20 (3): 598-599.

Gomez, K.A and Gomez, A.A. 1984. Statistical procedures for agricultural research (2nd Ed.). A Wiley Interscience Publication, NY, USA.

Gui-Fen Chen, Qi Zhan Tang, Yang -Rui Li , $\mathrm{Yu}-\mathrm{Yi}$ Huang, Bin Liu. Lii Xu and HaiRng Huang. (2012). Effect of sub soil dri fertigation on sugarcane in field conditions. Sugar Tech. 14(4): 418-421.

Hapse, D.G., Deshmukh, A.S. and Shinde, P.P. (1991). Micro irrigation in Sugarcane Agriculture. In Proceedings of the workshop on sprinkler and drip irrigation system held at Jalgon 8-10 Dec.1993, PP. 86-89.

Jackson,M.L. (1967). Soil Chemical Analysis. Asia Publishing House, Madras.

Kabita Mishra, (2019) Evaluation of bud chip method for enhancing yield and economics of sugarcane.

International Journal of Chemical studies, 7(3): 1726-1729.

Kapur, R Duttamajumdar, S.K. Krishna Rao, K.(2011) A breeders perspective on the tiller dynamics in sugarcane. Current Science.100:183-189.

Khandagave, R.B., Hapse, D.G. and Samaiya, S.S. (2005) Maximization of sugarcane yield and reduction of production costs a participatory rural appraisal. Silver jubilee congress Guatemala January 30 -February 4, Agriculture Commission.

Logananthan,N., Biksham Gujja, V., Vinod Goud and Natarajan, U.S. (2012) Sustainable Sugarcane initiative (SSI): A methodology of More with Less.
Journal of Sugar Tech DOI $10.1007 / \mathrm{s} 12355-012-0180$.

Naidu, N. V. (2003) Status of sugarcane and strategies for increasing cane productivity in Andhra Pradesh, Cooperative Sugars, Vol 34, No.9717722.

Narayanamorthy, A. (2013) Profitable in crops cultivation in India. Some evidences from cost of cultivation survey data. Indian Journal of Agricultural Economics.68 (1):104-121.

Pandian, B.J and Anbumani,S.2015. Productivity enhancement in sugarcane through crop establishment methods and irrigation techniques. In Proceedings of Joint Seminar by SISSTA \& Sugarcane Breeding Institute, Coimbatore. held on 24- 25 August 2015, Coimbatore, India. pp 115-121.

Patil, V.G., Dixit, R.M., Bhoite, D.S. and Bhoj, P.G. (2006) Effect of planting pattern under drip and surface irrigation in preseason and ratoon sugarcane. Proce. $67^{\text {th }}$ Ann. Conv. STAI: 183-190.

Sathiyaraj, M. and Sathyariya.2017.Irrigation Regimes and Fertigation Levels on Sugarcane under Sub surface Drip Fertigation. Int.J.Curr.Microbiol.App. Sci (2017) 6(11): 3674-3684.

Tamilselvan, N. (2006) Sugarcane response to chip bud method of planting. ISSCT Agronomy workshop held at Khonkaen, Tailand, pp.23-26.

Vijay Kumar, M. and Suresh, K. (2010) Studies on the physiological aspects of growth, quality and yield of bud chip technology in sugarcane. First National seminar on SSI.pp.44-46.

Vinodgoud, V. (2011). Sustainable Sugarcane Initiative: SSI-A Methodology for improving yields. In Proceedings of First National Seminar on Sustainable Sugarcane Initiative- A Methodology to Improve Cane Productivity held on 2425August, Tamil Nadu Agricultural 
University, Coimbatore, India. p8.

Walkey, A. and Black, I.A. 1934. An examination of Degtjareff method for determining soil organic matter and a proposed modification of the chromic acid titration method. Soil.Sci.37: 29-37.
Waykar, K.R., Mali, B.K., Sale, Y.C., and Bhosale, A.B.(2003). Drip irrigation System. A. Sustainable way for sugar production. Indian Journal of Agricultural Economics. 58 (3): 498499.

\section{How to cite this article:}

Anbumani. S., E. Jamuna and Pandian. M. 2020. Sugarcane Productivity Influenced by Irrigation Techniques and Crop Establishment Methods. Int.J.Curr.Microbiol.App.Sci. 9(04): 817-825. doi: https://doi.org/10.20546/ijcmas.2020.904.098 